\section{Attributable fraction of work accidents related to occupational noise exposure in a Southeastern city of Brazil}

\author{
Fração atribuível de acidentes do trabalho \\ decorrentes da exposição ao ruído ocupacional \\ em cidade do Sudeste do Brasil
}

\author{
1 Faculdade de Ciências \\ Médicas, Universidade \\ Estadual de Campinas, \\ Campinas, Brasil. \\ 2 Faculdade de Medicina \\ de Botucatu, Universidade \\ Estadual Paulista, Botucatu, \\ Brasil. \\ Correspondence \\ A. Dias \\ Departamento de Medicina \\ Preventiva e Social, \\ Faculdade de Ciências \\ Médicas, Universidade \\ Estadual de Campinas. \\ Rua Nelo Cariola 252. \\ Botucatu, SP \\ 18603-570, Brasil. \\ adias@fmb.unesp.br
}

\begin{abstract}
Noise is the most frequent type of occupational exposure and can lead to both auditory and extra-auditory dysfunction as well as increasing the risk of work accidents. The purpose of this study was to estimate the attributable fraction of work accidents related to occupational noise exposure in a medium-sized city in Southeast Brazil. In this hospital-based case-control study, including 600 cases and 822 controls, the odds ratio of work accidents (controlled for several covariables) was obtained classifying occupational noise exposure into four levels and determining the prevalence at each level. Based on these data, the calculated attributable fraction was 0.3041 (95\%CI: 0.2341 0.3676), i.e., $30 \%$ of work accidents in the study area were statistically associated with occupational noise exposure. The authors discuss the causes of this association and the implications for the prevention of work accidents.
\end{abstract}

Occupational Noise; Occupational Accidents; Attributable Risk
Adriano Dias 1,2

Ricardo Cordeiro 1

\section{Introduction}

Noise has accompanied humankind since time immemorial. Exposure to noise became more intense and prevalent, with a universal scope, when it began involving the work environment. Noise is currently considered the most common form of occupational exposure 1,2,3,4 and submits millions of workers to various injuries in activities like metallurgy, steel-making, carpentry, mining, transportation, and others.

The principal harm caused by occupational noise is noise-induced hearing loss, an irreversible disorder with an insidious onset that deteriorates hearing and thus the communications capacity of exposed workers. Noise can also have extra-auditory repercussions (cardiovascular 5, endocrine 6,7, and gastrointestinal 8).

Added to the above-mentioned auditory and non-auditory pathophysiological alterations, the specialized literature indicates that workers exposed to intense occupational noise present a two- to fourfold risk of accidents as compared to unexposed workers 9,10,11,12,13,14,15. Thus, noisecontrol and hearing conservation programs aim both to prevent exposure and hearing loss as well as to reduce the risk of work accidents 11,16.

Given this scenario, the aim of this study was to estimate the attributable fraction of work accidents related to occupational noise exposure in a medium-sized city in Southeast Brazil. 


\section{Method}

This research was part of a wider study aimed at improving workers' health surveillance activities in the municipality (county) of Piracicaba, São Paulo State, Brazil, called Diagnosis and Control of Work Accidents in Piracicaba (DIATEP) 17,18,19. A hospital-based case-control study was conducted with local workers as the source population. The study focused on occupational noise exposure as a risk factor, among others, for work accidents.

Case inclusion criteria were: residing in the city of Piracicaba, age 15-60 years, treatment for a typical work accident at the Emergency Department of the Piracicaba Orthopedics and Trauma Center (COT), and agreeing to participate in the study, signing an informed consent form. Inclusion criteria for controls were: belonging to the workforce (not unemployed), residing in the city of Piracicaba, age 15-60 years, treatment at the COT for any reason other than a work accident (or accompanying a patient receiving treatment there), and agreeing to participate in the study, signing an informed consent form. There is no reason to believe that if the controls had suffered work accidents during the study period they would have been treated in other hospitals.

After explaining the study's objectives and obtaining informed consent to participate, data were obtained from cases and controls by trained interviewers with a questionnaire on various occupational and non-occupational variables.

Investigation of noise exposure was based on the following question: "What is the normal intensity of noise in your workplace?", with four possible answers: "none", "low", "medium", and "high".

In developing the analysis, investigation of the possible relationship between occupational noise exposure and the occurrence of work accidents involved adjustment of a multiple logistic regression model 20 , in which the categorical and dichotomous response variable was the occurrence of an accident (control $=0$, case $=1$ ) and the predictive variable was the perception of exposure to occupational noise expressed by the worker, categorized according to the four levels mentioned above and controlled according to major occupational group 21, years of schooling, sex, and age bracket. The noise exposure levels were treated as dummy variables, with "non-exposure" as the baseline level. Further methodological details are provided in Dias et al. 22 .

Finally, calculation of the attributable fraction of work accidents related to occupational noise exposure used the usual equation $23,24,25$, adapted by the authors of the current study to express the different exposure levels:

$A F=\sum_{i}\left(\frac{P_{i}\left(R R_{i}-1\right)}{P_{i}\left(R_{i}-1\right)+1}\right)$ (1)

where: $\mathrm{AF}=$ attributable fraction; $\mathrm{i}=$ different noise exposure levels used in the study; $\mathrm{P}_{\mathrm{i}}=$ prevalence of workers exposed to noise level $\mathrm{i}$ in the source population; $\mathrm{RR}_{\mathrm{i}}=$ work accident incidence rate ratio (relative risk), comparing workers exposed to noise level $\mathrm{i}$ and workers unexposed to occupational noise in the source population.

The prevalence rates of workers exposed to noise level $i$ in the source population were estimated by the prevalence rates of these workers observed among the controls in the study. The relative risks $\left(\mathrm{RR}_{\mathrm{i}}\right)$ were estimated by the respective odds ratios (OR) obtained in the case-control study as cited above.

Calculation of confidence intervals for the attributable fraction used a log transformation proposed by Walter 26 , adapted by the authors of the current study:

$\mathrm{L}_{1-\alpha / 2}=\left[1-(1-\mathrm{AF}) \exp \left\{\mathrm{z}_{1-\alpha / 2} \sqrt{\frac{\sum_{\mathrm{i}} \mathrm{n}_{\mathrm{i}}}{\mathrm{nn}_{0}}+\frac{\sum_{\mathrm{i}} \mathrm{m}_{\mathrm{i}}}{\mathrm{mm}_{0}}}\right\}\right]$

$U_{1-\alpha / 2}=\left[1-\frac{1-A F}{\exp \left\{z_{1-\alpha / 2} \sqrt{\frac{\sum_{i} n_{i}}{n n_{0}}+\frac{\sum_{i} m_{i}}{m m_{0}}}\right\}}\right]$

where: $\mathrm{AF}=$ attributable fraction; $\mathrm{i}=$ different levels of noise exposure used in the study; $\mathrm{z}_{1-\alpha / 2}=100(1-\alpha / 2)^{0}$ percentile of the standard normal distribution; $\mathrm{n}_{\mathrm{i}}=$ number of cases exposed to noise level $\mathrm{i} ; \mathrm{n}_{0}=$ number of cases unexposed to noise; $\mathrm{n}=$ total cases; $\mathrm{m}_{\mathrm{i}}=$ number of controls exposed to noise level $\mathrm{i} ; \mathrm{m}_{0}=$ number of controls unexposed to noise; $\mathrm{m}=$ total controls.

The study was approved by the Institutional Review Board of the Botucatu School of Medicine, São Paulo State University.

\section{Results}

The data were collected on all workdays from May 16 to October 29, 2004, totaling 600 cases and 822 controls.

Table 1 shows the age distribution of all the work accident cases, emphasizing that more than $53 \%$ occurred in young adults ( $\leq 30$ years), 
with $12 \%$ among individuals 20 years or younger. Young workers also comprised the majority of the controls.

Table 2 shows the distribution by occupational group 19 among cases and controls.

The most frequent accidents were blunt injuries $(46.82 \%)$, followed by sprains (14.88\%), sharp/blunt injuries (10.36\%), and fractures (9.03\%), affecting mainly the hands (36.63\%), feet $(18.39 \%)$, upper limbs (14.71\%), lower limbs (14.04\%), and spinal column $(9.36 \%)$. The immediate causes of the accidents were mostly related to machinery and equipment (23.74\%), falling objects (23.57\%), excess effort or weight (13.04\%), and falls (8.53\%).
Applying the above-mentioned multivariate logistic model, the variables "worker reports medium-intensity noise at work" and "worker reports high-intensity noise at work" appeared as risk factors for work accidents, with adjusted ORs of 1.630 ( $\mathrm{p}=0.0037$; 95\%CI: 1.172-2.268) and 2.294 ( $\mathrm{p}<0.0001 ; 95 \%$ CI: 1.513-3.479), respectively. Table 3 shows the statistics obtained by this adjustment.

No statistically significant interaction term was observed ( $\alpha=0.05)$ among the selected variables. Analyzing the adjustment residues, no violations were observed in the logistic model's premises. All of the analyses used SAS, version 9.1.3 (SAS Institute, Cary, USA).

\section{Table 1}

Distribution of work accident cases and controls by age in a case-control study on occupational noise and work accidents. Piracicaba, São Paulo State, Brazil, 2004.

\begin{tabular}{|c|c|c|c|c|}
\hline \multirow[t]{2}{*}{ Age (years) } & \multicolumn{2}{|c|}{ Proportion of cases } & \multicolumn{2}{|c|}{ Proportion of controls } \\
\hline & $\mathbf{n}$ & $\%$ & $\mathbf{n}$ & $\%$ \\
\hline $15-20$ & 73 & 12.2 & 73 & 8.9 \\
\hline $21-30$ & 249 & 41.5 & 343 & 41.7 \\
\hline $31-40$ & 130 & 21.7 & 233 & 28.3 \\
\hline $41-50$ & 114 & 19.0 & 133 & 16.2 \\
\hline $51-60$ & 34 & 5.7 & 40 & 4.9 \\
\hline Total & 600 & 100.0 & 822 & 100.0 \\
\hline
\end{tabular}

$\chi^{2}=11.727 ;$ d.f. $=4 ; p=0.019$

Distribution of cases and controls according to occupational group in a case-control study on occupational noise and work accidents. Piracicaba, São Paulo State, Brazil, 2004.

\begin{tabular}{lcccc}
\hline Occupation & \multicolumn{2}{c}{ Proportion of cases } & Proportion of controls \\
& $\mathbf{n}$ & $\%$ & $\mathbf{n}$ & $\%$ \\
\hline Managers & 3 & 0.5 & 14 & 1.7 \\
Scientists & 7 & 1.2 & 33 & 4.0 \\
Technicians & 15 & 2.5 & 57 & 6.9 \\
Administrative & 27 & 4.5 & 64 & 7.8 \\
Services & 130 & 21.7 & 217 & 26.4 \\
Agriculture & 6 & 1.0 & 14 & 1.7 \\
Blue collar & 349 & 58.2 & 343 & 41.7 \\
Maintenance & 46 & 7.7 & 53 & 6.4 \\
Other & 3 & 0.5 & 16 & 1.9 \\
N.A. & 14 & 2.3 & 11 & 1.3 \\
Total & 600 & 100.0 & 822 & 100.0 \\
\hline
\end{tabular}

$\chi^{2}=65.310 ;$ d.f. $=9 ; p<0.001$. 
Table 3

Statistics obtained from multivariate logistic analysis in a case-control study on occupational noise and work accidents.

Piracicaba, São Paulo State, Brazil, 2004.

\begin{tabular}{|c|c|c|c|}
\hline Variable & Estimated $\beta$ parameter & $\mathrm{p}$ & OR $(95 \% \mathrm{Cl})$ \\
\hline Age & -0.0059 & 0.3197 & $0.994(0.983-1.006)$ \\
\hline Worker reports low-intensity noise at work & 0.2856 & 0.1089 & $1.331(0.938-1.887)$ \\
\hline Worker reports medium-intensity noise at work & 0.4888 & 0.0037 & $1.630(1.172-2.268)$ \\
\hline Worker reports high-intensity noise at work & 0.8303 & $<0.0001$ & $2.294(1.513-3.479)$ \\
\hline Technicians * & -0.0466 & 0.9288 & $0.954(0.343-2.653)$ \\
\hline Managers * & -0.1337 & 0.8635 & $0.875(0.191-4.013)$ \\
\hline Administrative * & 0.4107 & 0.4025 & $1.508(0.576-3.945)$ \\
\hline Agriculture * & 0.2177 & 0.7434 & $1.243(0.338-4.579)$ \\
\hline Maintenance * & 0.8777 & 0.0686 & $2.405(0.935-6.187)$ \\
\hline Blue collar * & 0.9747 & 0.0287 & $2.650(1.107-6.348)$ \\
\hline Services * & 0.6261 & 0.1668 & $1.870(0.770-4.544)$ \\
\hline Schooling (years) & -0.0894 & $<0.0001$ & $0.922(0.889-0.956)$ \\
\hline
\end{tabular}

$\chi^{2}$ goodness of $\mathrm{fit}=98.6564 ;$ d.f. $=12 ; \mathrm{p}<0.0001$

* Major occupational groups, Brazilian Classification of Occupations 21.

Of the 600 cases analyzed, 260 reported exposure to medium-intensity and 103 to high-intensity noise. Among the 822 controls, 313 and 79 reported exposure to medium- and high-intensity noise, respectively. When these results were applied to equation (1), the attributable fraction of work accidents in Piracicaba related to mediumand high-intensity occupational noise exposure was 0.3041 (95\%CI: 0.2341-0.3676).

\section{Discussion}

Piracicaba is located in the State of São Paulo and has a current population of some 345 thousand. It is a major industrial and agricultural center in the interior of the State, with an important industrial complex, including metallurgy, mechanics, paper, food processing, and agribusiness.

Attributable fraction informs the fraction of all cases of a disease or injury in the study population that is attributable to a given exposure or set of exposures. As an epidemiological concept, it relates the relative risk of a disease or injury to the prevalence of the exposures believed to be causally related to it. It is usually interpreted as the percentage of cases (e.g., accidents) occurring in a population that would have been avoided if the exposure to a causal factor (in this case noise) were eliminated 27 . This explains its usefulness in public health, particularly when choosing between alternative strategies for preventing 27 and controlling the exposure. The concept emerged in 195328 with the term "attributable risk", and its properties were studied by Walter 26 in 1975 . However, the expression "attributable risk" came to be used to designate the difference between incidences of exposed and unexposed populations 29,30 . In the current paper, we thus prefer the term "attributable fraction", first used by Walter 31 in 1976. The same concept has also been referred to by Cole \& MacMahon as population attributable risk percent ${ }^{32}$, by Miettinen 33 as etiological fraction, and by Greenland \& Robins 34 as excess fraction.

In practice, occupational noise exposure is known to occur at different levels, depending on each worker's occupational specificities. Since it is impossible to obtain a refined measurement of noise exposure for each worker studied here, the authors chose to use the workers' perception of their exposure, categorized in four levels. This approach resulted in three estimates for work accident risk, as a function of the level of noise exposure reported by the worker, using nonexposure as the baseline level in all cases. That is, ORs equal to 1 (non-significant in relation to baseline), 1.630, and 2.294, were obtained, respectively, for workers who reported exposure to low-, medium-, and high-intensity noise.

Originally, attributable fraction is estimated in relation to a homogeneous exposure $23,24,25$. In the current study, the authors chose to estimate it as the result of the existence of three exposure levels in the study population, which was done by generalizing the traditional estimator of attributable fraction $23,24,25$ to a situation with different exposure levels. 
The use of exposure prevalence (low, medium, and high) in the control group is justified as an estimator of prevalence in the source population, since this is precisely the function of controls in case-control studies 23.

Since this was a hospital-based case-control study in which cases occurred at an annual incidence rate of $3.3 \%$ in the source population 17 and work accidents are thus a rare event (i.e., incidence $<10 \%$ per year 20,23), the use of OR is justified as an estimator of relative risk (RR) 35 , used in obtaining the attributable fraction.

The study estimated that $30.4 \%$ of work accidents were attributable to occupational noise exposure in Piracicaba in 2004. This means that nearly one-third of work accidents in Piracicaba would be averted if workers' exposure to noise were eliminated, assuming that this is one of the causal factors of work accidents. Verification of this condition is a complex and difficult task 36,37 .

The statistical association shown here between occupational noise and work accidents has also been identified by other authors 9,10,11,12,13,14, which speaks in favor of the existence of a causal relationship between these two variables. However, it is important to note that noisy environments can (and usually do) contain other occupational risks for accidents besides noise per se. Thus, the relationship between noise and accidents could represent a bias. However, the risk estimate used to calculate the attributable fraction in the logistic analysis was controlled for gender, age group, schooling, and major occupational group, among other variables. This was a strategy to at least par- tially control for the possible confounding arising from the lack of comparability between cases and controls in relation to other known occupational risks besides noise.

Another important issue in evaluating causality is so-called plausibility. It appears quite plausible that noise acts as a causal factor for accidents, since it creates communications difficulties for workers (in the detection, discrimination, location, and identification of sound sources, as well as in speech intelligibility) 11,38 , maintenance of attention and concentration 39,40, and memory 39 , in addition to stress $10,41,42$ and excessive fatigue 40,41 . These factors are known to be involved in the genesis of work accidents.

Breslow \& Day 25 recommend that in the absence of evidence on causality, a cautious interpretation of attributable fraction be the proportion of cases explained by the exposure, where the term explained is used in the strict sense of statistical association.

Work accidents constitute an important public health problem worldwide, regardless of the country's degree of development. Despite the name, they are not "accidental" events 43 , but socially determined phenomena 44 , and are thus preventable. The attributable fraction estimated in this study justifies investment in hearing conservation programs focusing on the control of noise emissions at the source, aimed not only at maintaining healthy hearing but also decreasing workers' accident-proneness. Achieving this reduction will provide more evidence of the causal relationship between noise and accidents.

\section{Resumo}

O ruído é o mais freqüente dos agentes de exposição ocupacional. Pode proporcionar o desenvolvimento de disfunções auditivas e extra-auditivas, bem como o aumento do risco para acidentes do trabalho. O objetivo deste estudo foi estimar a fração de acidentes do trabalho atribuível à exposição ocupacional ao ruído, ocorridos em uma cidade de porte médio localizada no Sudeste do Brasil. A partir de um estudo caso-controle de base hospitalar, com 600 casos e 822 controles, obtiveram-se os odds ratio de acidentes do trabalho controlados para diversas covariáveis, relacionando trabalhadores expostos ao ruído em quatro níveis, bem como da prevalência destas exposições. Com estes resultados, estimou-se a fração atribuível como 0,3041 (IC95\%: 0,2341-0,3676), o que equivale a dizer que mais de $30 \%$ dos acidentes do trabalho ocorridos nesta localidade são estatisticamente associados à exposição ocupacional ao ruído. Discute-se a causalidade dessa relação e suas implicações para a prevenção dos acidentes do trabalho.

Ruído Ocupacional; Acidentes de Trabalho; Risco Atribuível 


\section{Contributors}

A. Dias participated in the study planning, data collection, data analysis, and drafting and review of the article. R. Cordeiro collaborated in the study planning, data analysis, and drafting and review of the article.

\section{Acknowledgments}

This study was conducted at the Reference Center for Workers' Health in Piracicaba and funded by the São Paulo State Research Foundation (Fundação de Amparo à Pesquisa do Estado de São Paulo - FAPESP grant 00/13719-3).

\section{References}

1. Alberti PW. Deficiência auditiva induzida pelo ruído. In: Lopes Filho O, Campos CAH, organizadores. Tratado de otorrinolaringologia. São Paulo: Editora Roca; 1994. p. 934-49.

2. Seligman J. Sintomas e sinais na PAIR. In: Nudelmann AA, Costa EA, Seligman J, Ibañez RN, organizadores. PAIR: perda auditiva induzida pelo ruído. Porto Alegre: Editora Baggagem; 1997. p. 143-51.

3. Baker DB, Landrigan PJ. Workers. In: Detels R, McEwen J, Beaglehole R, Tanaka H, editors. Oxford textbook of public health. Oxford: Oxford University Press; 2002. p. 1639-56.

4. Costa EA, Morata TC, Kitamura S. Patologia do ouvido relacionada com o trabalho. In: Mendes R, organizador. Patologia do trabalho. São Paulo: Editora Atheneu; 2003. p. 1254-82.

5. Rosenman KD. Cardiovascular disease and environmental exposure. Br J Ind Med 1979; 36:85-97.

6. Anticaglia JR, Cohen A. Extra-auditory effects of noise as a health hazard. Am Ind Hyg Assoc J 1970; 31:277-81.

7. Odescalchi CP. Effetti extra-auditivi del rumore: rumore a rendimento industriale. Med Lav 1970; 61:629-44.

8. Okamoto VA, Santos UP. Outros efeitos do ruído no organismo. In: Santos UP, organizador. Ruído: riscos e prevenção. São Paulo: Editora Hucitec; 1999. p. 89-91.
9. Cordeiro R, Clemente AP, Dias A, Diniz CS. Occupational noise as a risk factor for work-related injuries. Rev Saúde Pública 2005; 39:461-6.

10. Melamed S, Luz J, Green MS. Noise exposure, noise annoyance and their relation to psychological distress, accident and sickness absence among blue-collar workers - The Cordis Study. Isr J Med Sci 1992; 28:629-35.

11. Berger EH, Royster LH, Royster JD, Driscoll DP, Layne M. The noise manual. $5^{\text {th }}$ Ed. Akron: American Industrial Hygiene Association; 2000.

12. Moll van Charante AW, Mulder PG. Perceptual acuity and the risk of industrial accidents. Am J Epidemiol 1990; 131:652-63.

13. Barreto SM, Swerdlow AJ, Smith PG, Higgins CD. A nested case-control study of fatal work related injuries among Brazilian steel workers. Occup Environ Med 1997; 54:599-604.

14. Kjellberg A. Subjective, behavioral and psychophysiological effects of noise. Scand J Work Environ Health 1990; 16 Suppl 1:29-38.

15. Cohen A. Industrial noise and medical absence and accident record data on exposed workers. In: Proceedings of the International Congress on Noise as a Public Health Problem. Washington DC: US Environmental Protection Agency; 1976. p. 441-53. 
16. Cohen A. The influence of a company hearing conservation programme on extra-auditory problems in workers. J Safety Res 1976; 8:146-62.

17. Cordeiro R, Vilela RAG, Medeiros MAT, Gonçalves CGO, Bragantini CA, Varolla AJ, et al. O sistema de vigilância de acidentes do trabalho de Piracicaba, São Paulo, Brasil. Cad Saúde Pública 2005; 21 : 1574-83.

18. Cordeiro R, Vilela RAG, Medeiros MAT, Gonçalves CGO, Bragantini CA, Stephan C, et al. A system for occupational injury surveillance in a city in southeastern Brazil. New Solut; in press.

19. Bailey TC, Cordeiro R, Lourenço RW. Semi-parametric modeling of the spatial distribution of occupational accident risk in the casual labor market, Piracicaba, southeast Brazil. Risk Anal; in press.

20. Hosmer Jr. D, Lemeshow S. Applied logistic regression. New York: John Wiley and Sons; 2000.

21. Instituto Brasileiro de Geografia e Estatística. Classificação de ocupações - censo demográfico de 2000. http://www.ibge.gov.br/concla/ocupacao/ cbo/cbo.shtm (accessed on 01/Jul/2002).

22. Dias A, Cordeiro R, Gonçalves CGO. Exposição ocupacional ao ruído e acidentes do trabalho. Cad Saúde Pública 2006; 22:2125-30.

23. Rothman KJ, Greenland S. Modern epidemiology. Philadelphia: Lippincott-Raven; 1998.

24. Schlesselman JJ. Case-control studies: design, conduct, analysis. New York: Oxford University Press; 1982.

25. Breslow NE, Day NE. Statistical methods in cancer research. Volume 1 - The analysis of case-control studies. Lyon: YARC Press; 1980.

26. Walter SD. The distribution of Levin's measure of attributable risk. Biometrika 1975; 62:371-4.

27. Coughlin SS, Jacques B, Weed DL. Attributable risk estimation in case-control studies. Epidemiol Rev 1994; 16:51-64

28. Levin ML. The occurrence of lung cancer in man. Acta Unio Int Contra Cancrum 1953; 9:531-41.

29. Pereira MG. Interpretação da relação causal. In: Pereira MG, organizador. Epidemiologia: teoria e prática. Rio de Janeiro: Editora Guanabara Koogan; 2002. p. 398-417.

30. Leser W, Barbosa V, Baruzzi RG, Ribeiro MBD, Franco LJ. Etapas do método epidemiológico. In: Leser W, Barbosa V, Baruzzi RG, Ribeiro MBD, Franco LJ, organizadores. Elementos de epidemiologia geral. São Paulo: Editora Atheneu; 2002. p. 13-58.
31. Walter SD. The estimation and interpretation of attributable risk in health research. Biometrics 1976; 32:829-49.

32. Cole P, MacMahon B. Attributable risk percent in case-control studies. Br J Prev Soc Med 1971; 25:242-4.

33. Miettinen OS. Proportion of disease caused or prevented by a given exposure, trait or intervention. Am J Epidemiol 1974; 99:325-32.

34. Greenland S, Robins JM. Conceptual problems in the definition and interpretation of attributable fractions. Am J Epidemiol 1988; 128:1185-97.

35. Cordeiro R. O mito da doença rara. Rev Bras Epidemiol 2005; 8:111-6.

36. Weed DL. On the logic of causal inference. Am J Epidemiol 1986; 123:965-79.

37. Susser M. What is a cause and how do we know one? A grammar for pragmatic epidemiology. Am J Epidemiol 1991; 133:635-48.

38. Hétu R, Quoc HT. Psychoacoustic performance in workers with NIHL. In: Axelsson A, Borchgrevink H, Hamernik RP, Hellstrom P, Henderson D, Salvi RJ, editors. Scientific basis of noise-induced hearing loss. New York: Thieme; 1996. p. 264-85.

39. Berglund B, Lindvall T. Community noise. Stockholm: World Health Organization; 1995.

40. Ribeiro HP, Lacaz FAC. Acidentes de trabalho. In: Departamento Intersindical de Estudos e Pesquisas de Saúde e dos Ambientes de Trabalho, organizador. De que adoecem e morrem os trabalhadores. São Paulo: Departamento Intersindical de Estudos e Pesquisas de Saúde e dos Ambientes de Trabalho; 1984. p. 65-85.

41. Ferreira Jr. M. Perda auditiva induzida pelo ruído. In: Ferreira Jr. M, organizador. Saúde no trabalho. São Paulo: Editora Roca; 2000. p. 262-85.

42. Gessinger R, Castoldi L, Fensterseifer LM. Efeitos psicossociais da perda auditiva induzida pelo ruído (PAIR). In: Nudelmann AA, Costa EA, Seligman J, Ibañez NR, organizadores. PAIR: perda auditiva induzida pelo ruído. Porto Alegre: Editora Baggagem; 1997. p. 251-4.

43. Tsai SP, Bernacki EJ, Dowd CM. The relationship between work-related and non-work-related injuries. J Community Health 1991; 16:205-12.

44. Dwyer T. Life and death at work: industrial accidents as a case of socially produced error. New York: Plenum Press; 1991.

Submitted on 19/May/2006

Final version resubmitted on 11/Dec/2006 Approved on 10/Jan/2007 